\title{
PENINGKATAN HASIL BELAJAR PKn SISWA MELALUI PENERAPAN MODEL PEMBELAJARAN INDUKTIF DI KELAS IV-A SD NEGERI NO. 056612 PASAR BATU
}

\author{
Ningwati \\ Guru Mata Pelajaran PKn di SD Negeri No. 056612 Pasar Batu \\ Surel : ning.wati@yahoo.com
}

\begin{abstract}
Improving Student Learning Outcomes Civic Education With Application Of Inductive Learning Model In Class IV-A SD Negeri No. 056612 Pasar Batu Second Semester T.A 2015/2016. This research aims to improve students' learning activities using Inductive Learning Model in class IV-A SD Negeri No. 056612 Pasar Batu. These research subjects are 20 students. The study lasted for two cycles can be concluded that 1) The results of student learning through the implementation of the Inductive Learning Model is based on observations of the two observers increased from the first cycle to the second cycle. 2) Activities of student learning through the implementation of the Direct Instruction learning model Inductive Learning Model increases from the first cycle to the second cycle.
\end{abstract}

Keywords: Inductive Learning Model, Student Learning Outcomes

\begin{abstract}
Abstrak : Peningkatan Hasil Belajar PKn Siswa Melalui Penerapan Model Pembelajaran Induktif Di Kelas IV-A SD Negeri No. 056612 Pasar Batu Semester Genap T.A 2015/2016. Penelitian ini bertujuan untuk meningkatkan aktivitas belajar siswa dengan menggunakan model pembelajaran Induktif di kelas IV-A SD Negeri No. 056612 Pasar Batu. Subjek penelitian ini berjumlah 20 orang siswa. Penelitian berlangsung selama dua siklus dapat disimpulkan bahwa 1) Hasil belajar siswa melalui penerapan model pembelajaran Induktif berdasarkan pengamatan kedua pengamat mengalami peningkatan dari siklus I ke siklus II. 2) Aktivitas belajar siswa melalui penerapan model pembelajaran Induktif meningkat dari siklus I ke siklus II.
\end{abstract}

Kata Kunci: Pembelajaran Induktif, Hasil Belajar Siswa

\section{PENDAHULUAN}

Tugas utama guru adalah bertanggung jawab membantu anak didik dalam hal belajar. Dalam proses belajar mengajar, gurulah yang menyampaikan pelajaran, memecahkan masalah-masalah yang terjadi dalam kelas, membuat evaluasi belajar siswa, baik sebelum, sedang maupun sesudah pelajaran berlangsung (Combs, 1984:1113). Untuk memainkan peranan dan melaksanakan tugas-tugas itu, seorang guru diharapkan memiliki kemampuan professional yang tinggi. Dalam hubungan ini maka untuk mengenal siswa-siswanya dengan baik, guru perlu memiliki kemampuan untuk melakukan diagnosis serta mengenal dengan baik cara-cara yang paling efektif untuk membantu siswa tumbuh sesuai dengan potensinya masing-masing.

Harapan yang tidak pernah sirna dan selalu guru tuntut adalah, bagaimana bahan pelajaran yang disampaikan guru dapat dikuasai oleh anak didik secara tuntas. Ini merupakan masalah yang cukup sulit yang dirasakan oleh guru. Kesulitan ini dikarenakan anak didik bukan hanya sebagai individu dengan segala keunikannya, tetapi mereka juga sebagai makhluk sosial dengan latar belakang yang berlainan. Paling sedikit ada tiga aspek yang membedakan anak didik yang satu dengan yang lainnya, 
Jurnal Guru Kita (JGK). Vol 1 (2) Maret 2017, hlm. 40-47

yaitu aspek intelektual, aspek psikologis, aspek biologis (Syaiful Sagala 2010:1).

Proses pembelajaran yang dilakukan guru memang dibedakan keluasan cakupannya, tetapi dalam konteks kegiatan belajar mengajar mempunyai tugas yang sama. Maka tugas mengajar bukan hanya sekedar menuangkan bahan pelajaran, tetapi teaching is primarily and always the stimulation of learner (Wetherington, 1986:131-136), dan mengajar tidak hanya dapat dinilai dengan hasil penguasaan mata pelajaran, tetapi yang terpenting adalah perkembangan pribadi anak, sekalipun mempelajari pelajaran yang baik, akan memberikan pengalaman membangkitkan bermacammacam sifat, sikap dan kesanggupan yang konstruktif.

Dengan tercapainya tujuan dan kualitas pembelajaran, maka dikatakan bahwa guru telah berhasil dalam mengajar. Keberhasilan kegiatan belajar mengajar tentu saja diketahui setelah diadakan evalusi dengan berbagai faktor yang sesuai dengan rumusan beberapa tujuan pembelajaran. Sejauh mana tingkat keberhasilan belajar mengajar, dapat dilihat dari daya serap anak didik dan persentase keberhasilan anak didik dalam mencapai tujuan pembelajaran khusus. Jika hanya tujuh puluh lima persen atau lebih dari jumlah anak didik yang mengikuti proses belajar mengajar mencapai taraf keberhasilan kurang (di bawah taraf minimal), maka proses belajar mengajar berikutnya hendaknya ditinjau kembali.

Peneliti sebagai guru PKn di SD Negeri No. 056612 Pasar Batu juga memiliki masalah tersendiri. Siswa kelas IV-A di SD Negeri 056612 Pasar Batu prestasi belajar PKn cenderung rendah. Di SD Negeri 056612 Pasar Batu juga tidak terdapat perpustakaan sebagai fasilitator untuk siswa lebih aktif dan mengembangkan pengetahuan mereka dengan mencari bahan ajar dan soal Matematika dari buku pendukung di perpustakaan. Dalam mengajar PKn, peneliti juga tidak menggunakan media. tidak tersedianya media ajar membuat siswa kurang semangat dalam mengikuti pelajaran.

Mayoritas pekerjaan orang tua siswa yakni karyawan, bertani dan guru PNS. Kondisi lingkungan, tingkat pendidikan dan pekerjaan orang tua siswa juga turut mempengaruhi sikap belajar siswa. Karena tingkat pendidikan orang tua siswa yang rendah, mengakibatkan kesadaran untuk mendorong anak sekolah ke jenjang yang lebih tinggi juga rendah. ditambah lagi karena orang tua sibuk bekerja, orang tua tidak dapat mengontrol sikap belajar anaknya. Hal di atas mengakibatkan rendahnya minat belajar siswa yang bermuara pada rendahnya aktivitas dan prestasi belajar siswa.

Berdasarkan latar belakang yang telah diuraikan di atas, maka yang menjadi pokok masalah dalam penelitian ini dapat dirumuskan sebagai berikut; 1) Apakah hasil belajar siswa meningkat dengan penerapan model pembelajaran Induktif pada mata pelajaran PKn di kelas IV-A SD Negeri Mengenal Sistem Pemerintahan Tingkat Pusat semester genap T.A 2015/2016?; 2) Apakah aktivitas belajar siswa meningkat dengan penerapan model pembelajaran Induktif pada mata pelajaran Pkn di kelas IV-A SD Negeri Mengenal Sistem Pemerintahan Tingkat Pusat T.A 2015/2016?;

Sehingga merujuk pada rumusan masalah maka penelitian ini ditujukan untuk; 1) Untuk mengetahui apakah hasil belajar siswa meningkat dengan penerapan model pembelajaran Induktif 
pada mata pelajaran Pkn semester genapl di kelas IV-A SD Negeri 056612 Pasar Batu T.A 2015/2016; 2) Untuk mengetahui apakah aktivitas belajar siswa meningkat dengan penerapan model pembelajaran Induktif pada mata pelajaran Pkndi kelas IV-A SD Negeri 056612 Pasar Batu semester genap T.A 2015/2016;

\section{METODE}

Tempat penelitian tindakan kelas ini adalah di SD No. 056612 Pasar Batu Jalan Pasar Batu Stabat Lama Kabupaten Langkat kelas IV-A tahun ajaran 2015/2016. Dan waktu penyelenggaraan penelitian ini adalah pada semester genap mulai dari bulan Februari 2016 sampai dengan Juni 2016.

Subjek penelitian tindakan kelas ini adalah siswa kelas IV-A SD Negeri No. 056612 Pasar Batu tahun ajaran 2015/2016 yang berjumlah 20 orang siswa. Adapun yang bertindak sebagai observer dalam penelitian ini adalah guru teman sejawat yaitu Irmalati, S.Pd dan Misdayanti, S.Pd.

Alat pengumpul data dalam penelitian ini adalah; 1) tes hasil belajar; 2) lembar aktivitas belajar siswa;

Penelitian ini menggunakan Penelitian Tindakan Kelas (PTK). PTK adalah suatu bentuk kajian yang bersifat reflektif oleh pelaku tindakan yang dilakukan untuk meningkatkan kemantapan rasional dari tindakan mereka dalam melaksanakan tugas, memperdalam pemahaman terhadap tindakan-tindakan yang dilakukan itu, serta memperbaiki kondisi dimana praktek pembelajaran tersebut dilakukan (dalam Mukhlis, 2000: 3).

Sesuai dengan jenis penelitian yang dipilih, yaitu penelitian tindakan, maka penelitian ini menggunakan model penelitian tindakan dari Kemmis dan
Taggart (dalam Sugiarti, 1997:6), yaitu berbentuk spiral dari sklus yang satu ke siklus yang berikutnya. Setiap siklus meliputi planning (rencana), action (tindakan), observation (pengamatan), dan reflection (refleksi). Langkah pada siklus berikutnya adalah perencanaan yang sudah direvisi, tindakan, pengamatan, dan refleksi. Sebelum masuk pada siklus I dilakukan tindakan pendahuluan yang berupa identifikasi permasalahan.

Metode Analisis Data pada penelitian ini digunakan metode deskriptif dengan membandingkan hasil belajar siswa sebelum tindakan dengan hasil belajar siswa setelah tindakan.

Langkah-langkah pengolahan data sebagai berikut:

1. Merekapitulasi nilai pretes sebelum tindakan dan nilai tes akhir Siklus I dan Siklus II.

2. Menghitung nilai rerata atau persentase hasil belajar siswa sebelum dilakukan tindakan dengan hasil belajar setelah dilakukan tindakan pada Siklus I dan Siklus II untuk mengetahui adanya peningkatan hasil belajar.

Yang menjadi indikator keberhasilan guru mengajar digunakan KKM mata pelajaran PKn di SD Negeri No. 056612 Pasar Batu dengan nilai 70 secara individual dan $85 \%$ secara klasikal.

\section{PEMBAHASAN}

Sebelum melakukan siklus I peneliti terlebih dahulu mengumpulkan data yang berhubungan dengan kondisi awal siswa. Untuk memperoleh data tersebut, peneliti memberikan ujian pretes yang mencakup seluruh indikator yang akan menjadi bahan ajar untuk 4 KBM (siklus I dan II). Adapun data yang diperoleh seperti pada tabel berikut: 
Tabel Distribusi Hasil Pretes

\begin{tabular}{|c|c|c|}
\hline Nilai & Frekunsi & Rata-rata \\
\hline 30 & 5 & \multirow{2}{*}{4} \\
\cline { 1 - 2 } 40 & 9 & \\
\cline { 1 - 1 } 50 & 4 & \\
\hline 60 & 2 & \\
\cline { 1 - 2 } Jumlah & 20 & \\
\hline
\end{tabular}

Berdasarkan data di atas dapat ditarik kesimpulan bahwa siswa tidak mempersiapkan diri sebelum mengikuti pembelajaran di sekolah. Siswa tidak membaca materi yang akan di pelajari di rumah. Siswa hanya mengharapkan penjelasan guru tanpa mencari tau maupun membekali diri. Hal ini menunjukan aktivitas belajar siswa rendah. Hal ini juga mengindikasikan kurangnya perhatian orang tua siswa terhadap pola belajar siswa, sehingga siswa tidak belajar di rumah sebelum mengikuti pembelajaran

Observasi menghasilkan data aktivitas belajar siswa yang belum begitu menunjukkan siswa aktif diskusi. Data hasil observasi aktivitas belajar siswa disajikan dalam Tabel .1.

\section{Tabel Skor Aktivitas Belajar Siswa}

\section{Siklus I}

\begin{tabular}{|c|l|c|c|}
\hline No & \multicolumn{1}{|c|}{ Aktivitas } & Skor & Proporsi \\
\hline 1 & $\begin{array}{l}\text { Menulis, } \\
\text { membaca }\end{array}$ & 18,3 & $37 \%$ \\
\hline 2 & Mengerjakan LKS & 16,3 & $33 \%$ \\
\hline 3 & $\begin{array}{l}\text { Bertanya pada } \\
\text { teman }\end{array}$ & 3,0 & $6 \%$ \\
\hline 4 & $\begin{array}{l}\text { Bertanya pada } \\
\text { guru }\end{array}$ & 9,5 & $19 \%$ \\
\hline 5 & $\begin{array}{l}\text { Yang tidak } \\
\text { relevan }\end{array}$ & 3,0 & $6 \%$ \\
\hline \multicolumn{2}{|c|}{ Jumlah } & 50 & $100 \%$ \\
\hline
\end{tabular}

Merujuk pada Tabel aktivitas dominan yang dilakukan siswa adalah menulis dan membaca (37\%) kondisi ini belum sesuai dengan yang diharapkan karena seharusnya aktivitas diskusi lebih dominan ketimbang aktivitas individual tersebut, sementara aktivitasi mengerjakan LKS dalam posisi kedua (33\%), bertanya pada guru (19\%) dan aktivitas bertanya pada teman dan yang tidak relevan adalah $6 \%$.

Pada akhir proses belajar mengajar siswa diberi tes Formatif I dengan tujuan untuk mengetahui tingkat keberhasilan siswa dalam proses belajar mengajar yang telah dilakukan. Adapun data hasil formatif pada Siklus I ditunjukkan Tabel

\section{Tabel Distribusi Hasil Formatif 1}

\begin{tabular}{|c|c|c|}
\hline Nilai & Frekunsi & Rata-rata \\
\hline 60 & 8 & \multirow{2}{*}{78} \\
\cline { 1 - 2 } 80 & 6 & \\
\cline { 1 - 2 } 100 & 6 & \\
\cline { 1 - 2 } Jumlah & 20 & \\
\hline
\end{tabular}

Merujuk pada Tabel tersebut, nilai terendah formatif I adalah 60 dan tertinggi adalah 100. Merujuk pada KKM sebesar 70 maka hanya 12 dari 20 orang siswa mendapat nilai ketuntasan atau ketuntasan klasikal tercapai sebesar $60 \%$. Nilai ini berada di bawah kriteria ketuntasan klasikal sebesar $85 \%$ sehingga dapat dikatakan KBM siklus I gagal memberi ketuntasan belajar dalam kelas yang belum tuntas KKM. Nilai rata-rata kelas adalah 78 masih di bawah KKM. Rendahnya hasil belajar siswa tidak terlepas dari rendahnya aktivitas belajar siswa. rendahnya aktivitas belajar siswa ditandai dengan tingginya aktivitas individual yakni membaca/menulis (37\%), dan tingginya aktivitas yang tidak relevan dengan KBM yakni (6\%). Dengan demikian maka peneliti berusaha melakukan tindakan perbaikan dalam melaksanakan pembelajaran siklus II yang dirasa perlu. 
Berdasarkan hasil belajar kognitif dan pengamatan siklus I menunjukkan bahwa masih terdapat beberapa permasalahan/kekurangan dalam pelaksanaan tindakan yang perlu diperbaiki secara lanjut. Beberapa kelemahan pada siklus I yang ditemukan dari faktor siswa yaitu:

a. Kemampuan siswa dalam kelompoknya masih kurang, bahkan ada satu yang tidak lulus KKM.

b. Anggota kelompok masih enggan dan malu bertanya pada temannya.

c. Masih ada siswa yang tidak mau tau dan menyerahkan permasalahan pada teman 1 kelompoknya.

d. Pemahaman siswa akan materi masih sangat rendah terlihat dari: pada KBM 1 tidak ada siswa yang mau maju dengan sukarela, bahkan saat guru menunjuk langsung pun siswa bersangkutan tidak mau sehingga menyita waktu yang cukup lama.

e. Suasana diskusi antar siswa masih kurang. Masih banyak siswa yang mencoba mengerjakan LKS seca individual dan tidak bertanya pada teman jika ada hal yang mereka tidak mengerti

f. Guru belum menggunakan media ajar.

Observasi yang dilakukan dua guru sejawat menghasilkan data aktivitas belajar siswa Siklus II yang mengalami perbaikan dibandingkan Siklus sebelumnya. Data hasil observasi aktivitas belajar siswa disajikan dalam Tabel.

Tabel Skor Aktivitas Belajar Siswa Siklus II

\begin{tabular}{|c|l|c|c|}
\hline No & Aktivitas & Skor & Proporsi \\
\hline 1 & $\begin{array}{l}\text { Menulis, } \\
\text { membaca }\end{array}$ & 16,5 & $33 \%$ \\
\hline
\end{tabular}

\begin{tabular}{|c|l|c|c|}
2 & $\begin{array}{l}\text { Mengerjakan } \\
\text { LKS }\end{array}$ & 18,5 & $37 \%$ \\
\hline 3 & $\begin{array}{l}\text { Bertanya pada } \\
\text { teman }\end{array}$ & 9,5 & $19 \%$ \\
\hline 4 & $\begin{array}{l}\text { Bertanya pada } \\
\text { guru }\end{array}$ & 4,5 & $9 \%$ \\
\hline 5 & $\begin{array}{l}\text { Yang tidak } \\
\text { relevan }\end{array}$ & 1,0 & $2 \%$ \\
\hline \multicolumn{2}{|l|}{ Jumlah } & 50 & $100 \%$ \\
\hline
\end{tabular}

Pada akhir proses belajar mengajar Siklus II siswa diberi tes Formatif II dengan tujuan untuk mengetahui tingkat keberhasilan siswa dalam proses belajar mengajar yang telah dilakukan. Adapun data hasil formatif pada Siklus II ditunjukkan Tabel.

\section{Tabel Distribusi Hasil Formatif II}

\begin{tabular}{|c|c|c|}
\hline Nilai & Frekunsi & Rata-rata \\
\hline 60 & 2 & \multirow{2}{*}{85} \\
\cline { 1 - 2 } 80 & 11 & \\
\hline 100 & 7 & \\
\cline { 1 - 2 } Jumlah & 20 & \\
\hline
\end{tabular}

Merujuk pada Tabel. nilai terendah untuk formatif II adalah 60 dan tertinggi adalah 100 dengan 2 orang siswa mendapat nilai dibawah KKM atau ketuntasan klasikal adalah sebesar $90 \%$. Nilai ini berada di atas $85 \%$ sehingga dapat dikatakan KBM siklus II telah berhasil memberi ketuntasan belajar pada siswa dalam kelas. Nilai rata-rata kelas adalah 85 dan telah memenuhi KKM

Berdasarkan data yang diperoleh selama siklus II, maka dapat diperoleh data sebagai berikut:

1. Terjadi peningkatan aktivitas belajar siswa dari siklus I ke siklus II. Hal ini dilihat dari meningkatnya aktivitas mengerjakan dari pada menulis, dan meningkatnya 
aktivitas bertanya pada teman dari pada bertanya pada guru.

2. Terjadi peningkatan prestasi belajar siswa. Pada siklus I rata-rata hasil belajar siswa yakni 78 menjadi 85 pada siklus II dan ketuntasan klasikal pada siklus I 60\% dan pada siklus II menjadi $90 \%$.

Dengan demikian hasil formatif II menyatakan bahwa pembelajaran siklus II telah berhasil meningkatkan hasil belajar siswa dan memberikan ketuntasan rata-rata hasil belajar serta mampu memberikan ketuntasan belajar secara klasikal. Aktivitas belajar siswa pada siklus II juga mengalami peningkan yang cukup signipikan. Berdasarkan dari seluruh data siklus II dapat disimpulkan bahwa siklus II berhasil meningkatkan aktivitas yang bermuara pada peningkatan hasil belajar siswa.

Sedangkan untuk perbaikan pembelajaran sudah tidak banyak yang harus di revisi. Hanya saja guru harus lebih terampil dalam membagi waktu dan menyiapkan media sebaik dan semanarik mungkin.

Berdasarkan data yang diperoleh selama 2 siklus maka terjadi peningkatan aktivitas belajar siswa. Perbandingan aktivitas antara siklus I dan siklus II dijabarkan sebagai berikut: aktivitas menulis dan membaca turun dari $37 \%$ menjadi $33 \%$. Hal ini cukup membuat peneliti senang, karena penurunan aktivitas membaca mengindikasikan bahwa siswa telah mempersiapkan diri dari rumah sebelum mengikuti pembelajaran di kelas, sehingga tidak butuh waktu banyak bagi siswa untu membaca. Aktivitas mengerjakan dalam diskusi yang meningkat dari $33 \%$ menjadi $37 \%$ menunjukkan perbaikan yang terjadi dalam proses pembelajaran di mana siswa lebih aktif dalam pelaksanaan diskusi. Sementara aktivitas bertanya pada teman naik dari $6 \%$ menjadi $19 \%$, hal ini mengindikasikan bahwa siswa telah lebih mandiri dalam berpikir dan lebih koperatif sehingga siswa tidak enggan bertanya pada teman. Aktivitas bertanya pada guru menurun dari 19\% menjadi 9\%. Aktivitas yang tidak relevan dengan KBM turun dari 6\% menjadi $2 \%$ yang menandakan perbaikan aktivitas belajar siswa.

Perbaikan aktivitas belajar siswa bermuara pada peningkatan prestasi belajar siswa. Pada siklus I nilai terendah formatif I adalah 60 dan tertinggi adalah 100. Merujuk pada KKM sebesar 70 maka hanya 12 dari 20 orang siswa mendapat nilai ketuntasan atau ketuntasan klasikal tercapai sebesar $60 \%$. Nilai ini berada di bawah kriteria ketuntasan klasikal sebesar 85\% sehingga dapat dikatakan KBM siklus I gagal memberi ketuntasan belajar dalam kelas bahkan ada 1 tutor yang belum tuntas KKM. Nilai rata-rata kelas adalah 78 masih di bawah KKM. Sedangkan nilai terendah untuk formatif II siklus II adalah 60 dan tertinggi adalah 100 dengan 2 orang siswa mendapat nilai dibawah KKM atau ketuntasan klasikal adalah sebesar $90 \%$. Nilai ini berada di atas $85 \%$ sehingga dapat dikatakan KBM siklus II telah berhasil memberi ketuntasan belajar pada siswa dalam kelas. Nilai rata-rata kelas adalah 85 dan telah memenuhi KKM.

Berdasarkan hasil belajar kognitif dan pengamatan siklus I menunjukkan bahwa masih terdapat beberapa permasalahan/kekurangan dalam pelaksanaan tindakan yang perlu diperbaiki secara lanjut. Beberapa kelemahan pada siklus I yang ditemukan dari faktor siswa yaitu: 
1. Kemampuan teman dalam kelompoknya masih kurang, bahkan ada satu yang tidak lulus KKM.

2. Anggota kelompok masih enggan dan malu bertanya pada temannya.

3. Masih ada siswa yang tidak mau tau dan menyerahkan permasalahan pada teman 1 kelompoknya.

4. Pemahaman siswa akan materi masih sangat rendah terlihat dari: pada KBM 1 tidak ada siswa yang mau maju dengan sukarela, bahkan saat guru menunjuk langsung pun siswa bersangkutan tidak mau sehingga menyita waktu yang cukup lama

5. Suasana diskusi antar siswa masih kurang. Masih banyak siswa yang mencoba mengerjakan LKS secara individual dan tidak bertanya pada tutor jika ada hal yang mereka tidak mengerti

6. Guru belum menggunakan media ajar.

Berdasarkan data yang diperoleh dan juga refleksi yang dilakukan, maka peneliti melakukan diskusi dengan tutor dari UNIMED dan LPMP, teman sejawat dan pengamat peneliti, serta dengan pendamping peneliti dari UNIMED. Adapun yang menjadi tujuan diskusi yakni untuk menentukan tindakan perbaikan yang akan dilakukan pada siklus II untuk memperbaiki kekurangan pada siklus I. Berdasarkan diskusi tersebut maka diputuskan tindakan perbaikan sebagai berikut:

1. Bercermin dari kegagalan seorang tutor memperoleh KKM, maka guru akan membimbing setiap kelompok di luar sekolah sebelum dilakukan pembelajaran di sekolah. Hal ini bertujuan agar masingmasing kelompok menguasai materi ajar lebih dalam dan mampu membimbing temannya satu kelompok selama diskusi karena sudah di bekali oleh guru sebelumnya.

2. Guru akan memberikan sanksi pada siswa yang tidak koperatif dan membuat keributan pada saat diskusi dan guru juga akan memberi sanksi bagi siswa yang tidak mengikuti aturan yang telah dibuat guru.

3. Untuk lebih memotifasi siswa, guru akan membuat media berupa cerita yang sesuai dengan materi ajar yang akan di tempel di depan kelas agar siswa lebih mudah memahami tentang materi ajar.

4. Guru memotivasi siswa untuk lebih giat dan aktif selama diskusi dengan mengembalikan hasil diskusi mereka dan juga menginformasikan bahwa siswa yang tampak aktif akan memperoleh nilai lebih dari temannya yang kurang aktif.

\section{KESIMPULAN}

Setelah data-data tes hasil belajar, dan aktivitas belajar siswa terkumpul kemudian data tersebut dianalisis. Hasil analisis tersebut dapat disimpulkan sesuai dengan rumusan masalah, yaitu :

1. Data aktivitas siswa menurut pengamatan pengamat pada siklus I antara lain membaca/menulis (37\%), Mengerjakan LKS (33\%), bertanya sesama teman (6\%), bertanya kepada guru (19\%), dan yang tidak relevan dengan KBM (6\%). Data aktivitas siswa menurut pengamatan pada siklus II antara lain membaca/menulis (33\%), mengerjakan LKS (37\%), bertanya sesama teman (19\%), bertanya 
kepada guru (9\%), dan yang tidak relevan dengan KBM (2\%).

2. Hasil belajar siswa dengan menggunakan model pembelajaran tutor sebaya mengalami peningkatan. Pada siklus I ketuntasan sebesar $60 \%$ dengan rata-rata 78 dan belum tuntas secara klasikal dan pada siklus II sebesar 90\% dengan rata-rata 85 menunjukkan tuntas secara individu dan kelas. Dengan demikian model pembelajaran Induktif dapat meningkatkan prestasi belajar PKn siswa.

\section{DAFTAR RUJUKAN}

Combs, P.H.dan Manzoor, A. (2004). Memerangi Kemiskinan di Dunis Ketiga Melalui Pendidikan Non-Formal. Jakarta: Rajawali.

Hariyanto. (2007). PKN Untuk sekolah Dasar Kelas V. Jakarta: Erlangga.

Mukhlis, Abdul. (Ed). 2000. Penelitian Tindakan Kelas. Makalah Panitian Pelatihan Penulisan Karya Ilmiah untuk Guru-guru se-kabupaten Tuban.

Ningwati. (2016). Penerapan Model Pembelajaran Induktif Dalam Peningkatan Aktivitas Belajar PKn Siswa Di Kelas IV-A SD Negeri No. 056612 Pasar Batu Semester Genap T.A 2015/2016. (PTK Karangan Sendiri).

\begin{tabular}{|c|c|c|c|}
\hline Sanjaya, & $\begin{array}{c}\text { W. } \\
\text { Pembelaj }\end{array}$ & $\begin{array}{l}\text { (2006). } \\
\text { ran. }\end{array}$ & $\begin{array}{l}\text { Strategi } \\
\text { Jakarta: }\end{array}$ \\
\hline & $\begin{array}{l}\text { Kencana } \\
\text { Group. }\end{array}$ & Prenada & Media \\
\hline
\end{tabular}

Syaiful, Sagala. (2010). Konsep dan Makna Pembelajaran. Bandung: Alfabeta.

Suluh Pramastuti. (2007). "Analisis Kebijakan Dividen: Pengujian Dividen Signalling Theory dan Rent Extraction Hypothesis". Tesis. Yogyakarta: Program Pascasarjana Jurusan Manajemen UGM.

Wetherington. H.C and W.H Walt. Burton. (1986). Teknik-Teknik Belajar dan Mengajar. (terjemahan) Bandung: Jemmars. 